\title{
ЕНЕРГІЯ ПРОРОСТАННЯ ТА ПОЛЬОВА СХОЖІСТЬ НАСІННЯ КАРТОПЛІ ВІД СХРЕЩУВАННЯ ТА САМОЗАПИЛЕННЯ
}

\author{
Подгаєцький Анатолій Адамович \\ доктор сільськогосподарських наук, профресор \\ Сумський національний аграрний університет, м. Суми, Україна \\ ORCID: 0000-002-2130-8835 \\ podgaje@ukr.net \\ Шаповал Роман Миколайович \\ аспірант \\ Сумський національний аграрний університет, м. Суми, Україна \\ ORCID: 0000-0002-8702-6523 \\ romanschapoval1995@meta.ua \\ Кравченко Наталія Володимирівна \\ доктор сільськогосподарських наук, доцент \\ Сумський національний аграрний університет, м. Суми, Україна \\ ORCID: 0000-002-4190-0924 \\ kravchenko_5@ukr.net
}

У статті наведені результати дослідження енергії проростання гібридного насіння за участю складних міжвидових гібридів та від їх самозапилення і сортів, а також лабораторної схожості виконаних у Сумському національному аграрному університеті в 2018 році. В окремих блоках комбінацій за участі однакової батьківської фрорми доведений значний вплив на енергію проростання гібридного насіння компонентів схрещування. Наприклад, серед чотирьох комбінацій із запилювачем міжвидовим гібридом білоруської селекції 212.110-12 різниця у прояві показника становила 15,2 \% з найменшим вираженням у комбінаціях з материнськими фрормами 83.58c52 i 85.291с12, відповідно, самозапилення чотиривидового гібрида та одноразового беккроса шестивидового гібрида.

Різниця за енергією проростання насіння у п'яти комбінаціях із запилювачем видом S. andigenum була 16,1%, проте у чотирьох (за винятком використання материнською формою одноразового беккроса шестивидового гібрида 86.96с32) вона виявилась 9,9\%. Близькі дані до викладених отримані у чотирьох комбінаціях за участі запилювачем міжвидового гібрида білоруської селекції 212.31-10.

Виявлений специфічний вплив компонентів схрещування на проростання гібридного насіння впродовж 5-9 діб. Найкращі результати отримані серед насіння з походженням 86.96c32 x S. andigenum - 28,3\%. Досить високими вони були ще в трьох популяціях за участю виду. Виняток становило використання материнською формою дворазового беккроса шестивидового гібрида 89.721 с81 - 9,2\%.

У 54,1\% комбінацій лабораторна схожість насіння становила 90 \% і більше з максимальним проявом показника в гібридного насіння Щедрик х Подолія - 96,8 \%. В іншої популяції за участі згаданої материнської форми також отримані високі результати - 95,4 \%.

Найвища енергія проростання насіння від самозапилення виявлена в сорту Ірбицька (90,8 \%) та міжвидових гібридів 81.436с4 і 81.1546с103 - по 90,0 \%. Протилежне стосувалось сорту Аніка (76,0 \%) та одноразового беккроса шестивидового гібрида 85.291с12 (77,2 \%). Максимальну лабораторну схожість мало насіння від самозапилення сорту Межирічка - 96,0 \% та чотиривидового гібрида 81.1546с103 - 97,5\%. Виявлено, що за енергією проростання гібридне насіння поступилось виділеному від самозапилення сортів на 6,0 \%, а міжвидових гібридів - на 5,2 \%, а щодо лабораторної схожості це, відповідно, становило 3,7 та 3,1 \%.

Лише в окремих комбінаціях: 90.691/21 х Світанок київський, 81.397с50 х 212.31с10 і 891.1546с103 енергія проростання насіння була вищою, ніж у насінні від самозапилення. Водночас, в популяції 83.58c52 x 212.110-12 різниця виявлена найбільшою та від'ємною - 16,1%. Щодо лабораторної схожості насіння тільки в двох комбінаціях: 90.691/21 x Світанок київський і 81.397с50 x 212.31-10 різниця з матеріалом від самозапилення була додатною, хоча і з невеликою різницею - 0,2 \%.

Ключові слова: картопля, складні міжвидові гібриди, сорти, гібридне насіння, насіння від самозапилення, енергія проростання насіння, лабораторна схожість.

DOI https://doi.org/10.32845/agrobio.2021.3.5

Вступ. Картопля - найважливіша у світі харчова культура (Meenakshi Kumari et al., 2018). Серед світового виробництва бульб близько $66 \%$ використовується як їжа, 12 \% - як корм для тварин і $10 \%$ - як насіння (FAO). Значною мірою викладене стало реальністю завдяки досягненням селекції культури, основу якої становить генетичне різноманіття вихідного матеріалу для гібридизації (Hayder et al., 2007; Yermishin et al., 2021), значну частину якого складають дикорослі та культурні види (Kiru \& Rogozina, 2017). Незважаючи на міжвидову 
несумісність в процесі міжвидової гібридизації картоплі (Pershina \& Trubacheeva, 2016; Gavrilenko \& Yermishin, 2017; Anisimova, 2017; Polyucjvich, 2018), усе більше дикорослих та культурних видів залучаються у селекційну практику. Завдяки гетерозису, основаному на гетероалелізмі (Muthoni et al., 2012), значна частина міжвидових гібридів перевищує сорти-стандарти за проявом численних господарсько-цінних ознак (Podhaietskyi, 2012; Podhaietskyi et. al., a, 2019; Podhaietskyi et. al., 2020). Крім цього, лише завдяки інтрогресії ефективних генів контролю стійкості проти численних збудників хвороб, шкідників від співродичів культурної картоплі у сорти (Rogozina \& Khavkin, 2017) вдалося вирішити проблеми, які ставили під сумнів можливість вирощування культури.

Згідно схеми, селекційний процес картоплі починається з гібридизації та вирощування сіянців першого року (Bondarchuk et al., 2019). Саме від цих етапів залежить загальний обсяг оцінюваних гібридів і сіянців від самозапилення. Складнощі у їх виконанні спостерігаються дослідниками повсякчас. Результати експериментів (Sobran et al., 2021) свідчать, що для гібридизації, у тому числі за участю міжвидових гібридів, сприятливим зовнішнім комплексом $€$ умови Українських Карпат. Лише в окремі роки у цьому місці не вдається отримати гібридні ягоди.

Не менш важливим для селекційного процесу є схожість ботанічного насіння картоплі. Згідно результатів дослідження (Hniteckyi, 2021) у окремих комбінаціях частка пророслого насіння була менше $80 \%$, а $з$ походженням Верді х Струмок становила тільки 6,9%. Метою експерименту було вивчення енергії проростання та лабораторну схожість гібридного насіння, отриманого від беккросування міжвидових гібридів та від самозапилення.

Матеріали і методи досліджень. Вихідним матеріалом для схрещування використані складні міжвидові гібриди за участі дикорослих: S. bulbocastanum Dun., S. demissum Lindl., S. acaule Bitt., та культурних: S. phureja Juz. et Buk., S. andigenum Juz. et Buk., S. tuberosum L. видів картоплі. У походженні окремих комбінацій запилювачем був зразок виду S. andigenum (A). Запилювачі популяції 212 отримані з Інституту картоплярства та овочівництва НАН республіки Білорусь. Буквою «П» позначались гібриди Поліського дослідного відділення Інституту картоплярства НААН України. Також використовувалось насіння від самозапилення сортів та міжвидових гібридів.

Методи виконання експерименту загальноприйняті для проведення селекційно-генетичних досліджень. Пророщували насіння в чашках Петрі, потім вирощували у посівних ящиках, парниках з наступною пересадкою у поле (Metodychni rekomendacii' shhodo provedennja doslidzhen' z kartopleju, 2002). Частину насіння одержали з Карпатського опорного пункту Інституту картоплярства НААН України (буква «з» після номера). Енергія проростання насіння визначалась за часткою пророслого насіння на четверту добу після намочування (Zhatova, 2010), а лабораторна схожість на дев'ятий день.

Результати. Як свідчать отримані дані (табл. 1), за енергією проростання комбінації значно різнились. Мінімальною величиною показника характеризувалась попу- ляція з походженням Аніка х 96.976/20 - 60,0 \%. Протилежне стосувалось комбінації П.09-1 х 11.24/46 - 94,0 \%, тобто з різницею у 34,0 \%. Водночас, слід відмітити, що у більшості комбінацій енергія проростання виявилась досить високою. У 17-ти популяціях частка насіння, яке наклюнулось у перші чотири доби, було менше $80 \%$ і тільки у п'яти вираження показника було нижче 70 \%.

Використання однакових запилювачів або материнських форм дозволило виявити вплив компонентів схрещування на енергію проростання насіння. У чотирьох популяціях запилювачем використано чотириразовий беккрос шестивидового гібрида - 96.976/20. Як свідчать отримані дані, найкращою материнською формою для згаданого гібрида щодо енергії проростання насіння виявився сорт Злагода (87,7 \% пророслого насіння). Протилежне стосувалось сорту Аніка з найменшим вираженням показника - 60,0 \%. Тобто, різниця серед цього блоку популяцій за вираженням показника становила 27,7%.

У чотирьох комбінаціях запилювачем був вид S. andigenum. У цьому випадку також мала місце значна різниця за енергією проростання насіння, що залежало від особливостей беккросів міжвидових гібридів. Найкращі результати отримані за використання материнською формою дворазового беккроса шестивидового гібрида 89.721с81 - 80,9 \%, а найгірші з дворазовим беккросом шестивидового гібрида 86.96с32 - 64,8 \%. Різниця між популяціями становила 16,1\%.

Особлива реакція за проявом показника мала місце у блоці комбінацій із гібридом Інституту картоплярства та плодоовочівництва НАН Республіки Білорусь 212-110-12. Вдалою материнською формою виявився одноразовий беккрос п'ятивидового гібрида 81.436c4 з часткою пророслого насіння на четверту добу 83,3 \%. Протилежне стосувалось материнської форми, одержаної від самозапилення чотиривидового гібрида 83.58c52 та одноразового беккроса шестивидового гібрида 85.291с12. У них отримані дуже близьке та низьке вираження показника, відповідно, 68,1 та 69,8 \%.

Вдалим поєднанням для отримання високої енергії проростання насіння було використання білоруського гібрида 212.31-10. В усіх трьох популяціях за його участю найнижчий прояв показника становив 79,5 \%, а різниця між комбінаціями виявилась мінімальною у досліді - 8,3 \%.

Значні відмінності між популяціями за вираженням ознаки мали місце також за участю компонентів схрещування сортів та міжсортових гібридів. Стосовно сорту Щедрик (материнська форма), серед чотирьох комбінацій кращим запилювачем був гібрид Поліського дослідного відділення П11.17-1 - 83,8 \%. Протилежне відносилось до сорту Ірбицька - 70,0 \%, тобто різниця між ними становила 13,8\%.

Найбільша частка пророслого насіння впродовж 5-9 доби - близько 30 \% виявлена тільки у двох популяціях: 86.96с32 х А та Джасія х 11.23/47. Не проросло жодної насінини у цей період у комбінації П.09.62-1 х 11.24/46 і дуже низьке вираження показника відмічено у популяції 81.1546с103 x 212.31-10 - 4,2 \%. У 20-ти комбінаціях з 37-ми частка пророслого насіння була $90 \%$ і більше. Водночас, у трьох вона не перевищила 76,7 \%, 
Таблиця 1

Енергія проростання та лабораторна схожість гібридного насіння (2018р.)

\begin{tabular}{|c|c|c|c|c|c|c|c|c|}
\hline \multirow[t]{2}{*}{$\begin{array}{c}\text { Комбінація, } \\
\text { № }\end{array}$} & \multirow[t]{2}{*}{ Походження } & \multirow[t]{2}{*}{$\begin{array}{c}\text { Закладено на } \\
\text { пророщування, шт. }\end{array}$} & \multicolumn{2}{|c|}{$\begin{array}{c}\text { Енергія } \\
\text { проростання }\end{array}$} & \multicolumn{2}{|c|}{$\begin{array}{c}\text { Проросло } \\
\text { на 5-9 } \\
\text { добу }\end{array}$} & \multicolumn{2}{|c|}{ Всього проросло } \\
\hline & & & шт. & $\%$ & шт. & $\%$ & шт. & $\%$ \\
\hline 1 & 2 & 3 & 4 & 5 & 6 & 7 & 8 & 9 \\
\hline 1 & Злагода x 96.976/20 & 267 & 225 & 84,3 & 23 & 8,6 & 248 & 92,9 \\
\hline 2 & Партнер х 96.976/20 & 161 & 132 & 82,0 & 14 & 8,7 & 146 & 90,7 \\
\hline 3 & $81.386 c 65 \times 212-110-12$ & 160 & 125 & 78,1 & 23 & 14,4 & 148 & 92,5 \\
\hline 4 & $81.386 c 65 \times 212.47-1$ & 250 & 215 & 86,0 & 20 & 8,0 & 235 & 94,0 \\
\hline 5 & $81.397 \mathrm{c} 50 \times 212.31-10$ & 188 & 165 & 87,8 & 9 & 4,8 & 174 & 92,6 \\
\hline 6 & $81.436 c 4 \times 212-110-12$ & 90 & 75 & 83,3 & 8 & 8,9 & 83 & 92,2 \\
\hline 7 & $81.436 c 4 \times 212.31-10$ & 83 & 66 & 79,5 & 5 & 6,0 & 71 & 85,5 \\
\hline 8 & $81.1546 c 103 \times 212.31-10$ & 72 & 61 & 84,7 & 3 & 4,2 & 64 & 88,9 \\
\hline 9 & $81.1546 \mathrm{c} 103 \times 212.47-1$ & 65 & 49 & 75,4 & 4 & 6,2 & 53 & 81,5 \\
\hline 10 & $81.397 c 50 \times 212.47-1$ & 267 & 205 & 76,8 & 34 & 12,7 & 239 & 89,5 \\
\hline 11 & $83.58 c 52 \times 212-110-12$ & 72 & 49 & 68,1 & 13 & 18,1 & 62 & 86,1 \\
\hline 12 & $85.291 \mathrm{c} 12 \times 212-110-12$ & 86 & 60 & 69,8 & 6 & 7,0 & 66 & 76,7 \\
\hline 13 & $85.291 \mathrm{c} 12 \times 212.47-1$ & 84 & 61 & 72,6 & 13 & 15,5 & 74 & 88,1 \\
\hline 14 & Аніка х 96.976/20 & 15 & 9 & 60,0 & 2 & 13,3 & 11 & 73,3 \\
\hline 15 & Злагода x 96.976/20 & 155 & 136 & 87,7 & 9 & 5,8 & 145 & 93,5 \\
\hline 16 & Злагода x 90.676/210 & 70 & 53 & 75,7 & 10 & 14,3 & 63 & 90,0 \\
\hline 17 & Іванківська р. x 90.676/210 & 189 & 136 & 72,0 & 36 & 19,0 & 172 & 91,0 \\
\hline 18 & $86.96 \mathrm{c} 32 \times \mathrm{A}$ & 446 & 289 & 64,8 & 126 & 28,3 & 415 & 93,0 \\
\hline 19 & $89.721 \mathrm{c} 81 \times \mathrm{A}$ & 251 & 203 & 80,9 & 23 & 9,2 & 226 & 90,0 \\
\hline 20 & $90.666 / 19 \times A$ & 162 & 115 & 71,0 & 21 & 13,0 & 136 & 84,0 \\
\hline 21 & $90.679 / 8 \times 212.31-10$ & 150 & 114 & 76,0 & 24 & 16,0 & 138 & 92,0 \\
\hline 22 & $90.679 / 8 \times A$ & 432 & 334 & 77,3 & 64 & 14,8 & 398 & 92,1 \\
\hline 23 & $90.690 / 61 \times A$ & 167 & 125 & 74,9 & 20 & 12,0 & 145 & 86,8 \\
\hline 24 & 90.691/21 x Св. київський & 181 & 151 & 83,4 & 10 & 5,5 & 161 & 89,0 \\
\hline 25 & 90.694/7 x Св. київський & 40 & 28 & 70,0 & 5 & 12,5 & 33 & 82,5 \\
\hline 13 & П 09.62-1х Околиця & 250 & 198 & 79,2 & 34 & 13,6 & 232 & 92,8 \\
\hline 23 & Джасія x 81.459c18 & 250 & 202 & 80,8 & 28 & 11,2 & 230 & 92,0 \\
\hline 33 & П.09.62-1х П.11.32/16 & 250 & 188 & 75,2 & 36 & 14,4 & 224 & 89,6 \\
\hline 43 & Джасія x П.11.23/47 & 250 & 157 & 62,8 & 84 & 33,6 & 241 & 96,4 \\
\hline 53 & П.09.62-1х П.11.24/46 & 250 & 235 & 94,0 & 0 & 0,0 & 235 & 94,0 \\
\hline 63 & Межирічка х П.11.23/47 & 234 & 186 & 79,5 & 12 & 5,1 & 198 & 84,6 \\
\hline 73 & Щедрик x Ірбицька & 250 & 175 & 70,0 & 16 & 6,4 & 191 & 76,4 \\
\hline 83 & Щедрик х П.11.17-1 & 99 & 83 & 83,8 & 6 & 6,1 & 89 & 89,9 \\
\hline 93 & П.09.62-1 x 81.197c14 & 250 & 216 & 86,4 & 20 & 8,0 & 236 & 94,4 \\
\hline 103 & 11.32/56 x Янка & 250 & 189 & 75,6 & 32 & 12,8 & 221 & 88,4 \\
\hline 113 & Щедрик x Батя & 216 & 178 & 82,4 & 28 & 13,0 & 206 & 95,4 \\
\hline 123 & Щедрик x Подолія & 154 & 125 & 81,2 & 24 & 15,6 & 149 & 96,8 \\
\hline
\end{tabular}

що свідчить про значний вплив компонентів схрещування на вираження показника. Поміж насіння від самозапилення найбільшу енергію проростання мав сорт Ірбицька - 90,8 \% (табл. 2). Протилежне стосувалось сорту Аніка - 76,0 \%, тобто з різницею між ними 14,8 \%, що, вважаємо значними відмінностями у характеристиці за проявом показника.

Серед міжвидових гібридів два мали енергію проростання 90,0 \%: одноразовий беккрос п'ятивидового гібрида 81.436с4 і чотиривидовий гібрид 81.1546с103. Навпаки, в одноразового беккроса шестивидового гібрида 85.291с12 величина показника становила 77,2 \% або на 12,8 \% менше, ніж у згаданого вище. У більшості популяцій від самозапилення сортів на 5-9 добу проросла значна кількість насіння. Максимально це виявлено в сорту Аніка - 18,0 \%, а найменшою величиною показника характеризувався сорт Ірбицька - 4,8 \%.

Інше, порівняно з викладеним вище, спостерігалось серед міжвидових гібридів, їх беккросів. За винятком трьох: 81.386c65, 81.397c50 і 85.291с12, величина показника була менше 10 \%. Максимальна кількість пророслого насіння відмічена поміж самозапилення шестивидового гібрида 81.397с50, а мінімальна $-81.436 c 4$, що також є шестивидовим гібридом. 
У цілому, тільки серед самозапилення сорту Світанок київський лабораторна схожість насіння становила менше $90 \%$, а максимальною вона була в сорту Межирічка - 96,0 \%. Різниця між сортами виявилась невеликою - 7,2 \%. Інше, порівняно з викладеним вище, стосувалось міжвидових гібридів, їх беккросів. Лабораторна схожість насіння від самозапилення дворазового беккроса чотиривидового гібрида 90.694/7 становила 85,0 \%, а чотиривидового гібрида 81.1546с103 -97,5\%. Тобто, різниця між ними сягала $12,5 \%$, що значно більше, ніж у сортів.

Результати проведення порівняння енергії проростання та лабораторної схожості насіння, залежно від його походження, наведені у табл. 3. За проявом першого показника значно поступалось гібридне насіння, порівняно з отриманим від самозапилення. Різниця поміж самозапилення сортів та гібридним насінням становила $6,0 \%$, а останнім та самозапиленням міжвидових гібридів, їх беккросів - 5,2 \%. Водночас, залежно від вихідного матеріалу за проявом показника, різниця самозапилення сортів та міжвидових гібридів, їх беккросів була невеликою - 0,8 \%.

Дещо інше спостерігалось щодо частки пророслого насіння на 5-9 добу після намочування. Відмінність між самозапиленням, залежно від вихідного матеріалу, становила тільки 0,1%, в гібридного насіння це виражалось
12,4 \%, тобто на 2,2 \% більше, порівняно з самозапиленням сортів, що, вважаємо невеликою різницею.

За проявом лабораторної схожості виділилось насіння від самозапилення сортів з проявом показника 94,2 \% (табл. 3). Лише на 0,6 \% поступалось йому самозапилення міжвидових гібридів, їх беккросів. Найнижче вираження показника відмічене серед гібридного насіння - 90,5\%.

Обговорення. Енергія проростання насіння та лабораторна схожість має велике значення не лише для селекційних цілей, але й для вирощування картоплі з ботанічного насіння (Kuchumov, 1990; Gordijenko \& Podgajec'kyj, 2000, Podgajec'kyj, 2002). Порівняння викладених даних з отриманими раніше в дослідженні гібридного насіння, одержаного за участю міжвидових гібридів, їх бекккросів та у результаті схрещування сортів свідчить, що за винятком декількох комбінацій мали місце близькі результати стосовно енергії проростання насіння i, особливо, його лабораторної схожості (Podgajec'kyj et al., b, 2019). В іншій роботі (Sobran, 2019) встановлений позитивний вплив на енергію проростання насіння, лабораторну схожість гібридного насіння окремих материнських форм, наприклад, дворазового беккроса шестивидового гібрида 08.195/73, на одному з етапів створення якого схрещували два міжвидові гібриди. Водночас, за енергією проростання комбінації

Енергія проростання та лабораторна схожість насіння

Таблиця 2 від самозапилення сортів та міжвидових гібридів (2018р.)

\begin{tabular}{|c|c|c|c|c|c|c|c|c|}
\hline \multirow{2}{*}{$\begin{array}{c}\text { Комбінація, } \\
\text { № }\end{array}$} & \multirow{2}{*}{ Походження } & \multirow{2}{*}{$\begin{array}{c}\text { Закладено на } \\
\text { проро-щування, } \\
\text { шт. }\end{array}$} & \multicolumn{2}{|c|}{$\begin{array}{c}\text { Енергія } \\
\text { проростання }\end{array}$} & \multicolumn{2}{|c|}{$\begin{array}{c}\text { Проросло } \\
\text { на 5-9 добу }\end{array}$} & \multicolumn{2}{|c|}{ Всього проросло } \\
\hline & & & шт. & $\%$ & шт. & $\%$ & шт. & $\%$ \\
\hline 1 & Аніка & 50 & 38 & 76,0 & 9 & 18,0 & 47 & 94,0 \\
\hline 2 & Злагода & 250 & 202 & 80,8 & 30 & 12,0 & 232 & 92,8 \\
\hline 3 & Світанок київський & 80 & 61 & 76,3 & 10 & 12,5 & 71 & 88,8 \\
\hline 4 & Межирічка & 250 & 212 & 84,8 & 28 & 11,2 & 240 & 96,0 \\
\hline 5 & Ірбицька & 250 & 227 & 90,8 & 12 & 4,8 & 239 & 95,6 \\
\hline 6 & $81.386 c 65$ & 70 & 56 & 80,0 & 11 & 15,7 & 67 & 95,7 \\
\hline 7 & $81.397 c 50$ & 200 & 157 & 78,5 & 34 & 17,0 & 191 & 95,5 \\
\hline 8 & $81.436 \mathrm{c} 4$ & 70 & 63 & 90,0 & 3 & 4,3 & 66 & 94,3 \\
\hline 9 & $81.459 c 18$ & 180 & 154 & 85,6 & 15 & 8,3 & 169 & 93,9 \\
\hline 10 & $81.1546 c 103$ & 80 & 72 & 90,0 & 6 & 7,5 & 78 & 97,5 \\
\hline 11 & $83.58 c 52$ & 120 & 101 & 84,2 & 11 & 9,2 & 112 & 93,3 \\
\hline 12 & $85.291 \mathrm{c} 12$ & 250 & 193 & 77,2 & 31 & 12,4 & 224 & 89,6 \\
\hline 13 & $90.694 / 7$ & 20 & 16 & 80,0 & 1 & 5,0 & 17 & 85,0 \\
\hline 14 & $96.976 / 20$ & 250 & 221 & 88,4 & 18 & 7,2 & 239 & 95,6 \\
\hline 15 & $212.31-10$ & 250 & 208 & 83,2 & 23 & 9,2 & 231 & 92,4 \\
\hline
\end{tabular}

Таблиця 3

Енергія проростання та лабораторна схожість насіння залежно від особливостей вихідного матеріалу (2018 р.)

\begin{tabular}{|c|c|c|c|c|c|c|c|c|}
\hline \multirow{2}{*}{\multicolumn{2}{|c|}{ Походження }} & \multirow{2}{*}{$\begin{array}{c}\text { Закладено на } \\
\text { пророщування, шт. }\end{array}$} & \multicolumn{2}{|c|}{$\begin{array}{c}\text { Енергія } \\
\text { проростання }\end{array}$} & \multicolumn{2}{|c|}{$\begin{array}{l}\text { Проросло } \\
\text { на 5-9 добу }\end{array}$} & \multicolumn{2}{|c|}{$\begin{array}{c}\text { Всього } \\
\text { проросло }\end{array}$} \\
\hline & & & шт. & $\%$ & шт. & $\%$ & шт. & $\%$ \\
\hline \multicolumn{2}{|c|}{ Гібридне насіння } & 6806 & 5313 & 78,1 & 845 & 12,4 & 6158 & 90,5 \\
\hline \multirow[b]{2}{*}{ Самозапилення } & сортів & 880 & 740 & 84,1 & 89 & 10,2 & 829 & 94,2 \\
\hline & $\begin{array}{c}\text { беккросів міжвидових } \\
\text { гібридів }\end{array}$ & 1490 & 1241 & 83,3 & 153 & 10,3 & 1394 & 93,6 \\
\hline
\end{tabular}

Вісник Сумського національного аграрного університету 
з материнською формою сортом Верді значно різнились. В наших дослідженнях виявилась можливість порівняти за життєздатністю насіння, отриманого від схрещування та самозапилення однієї з батьківських форм. У двох популяціях за участі запилювачем сорту Світанок київський енергія проростання насіння мала як додатне $(+7,1)$, так і від'ємне $(-6,3)$ відхилення від прояву ознаки серед самозапилення сорту (табл. 4).

Значна та від'ємна різниця у прояві показника мала місце за порівняння самозапилення шестивидового гібрида 81.436с4 та двох комбінацій за його участю: - 6,7 та - 10,5\%. Аналогічне стосувалось самозапилення чотиривидового гібрида 83.58c52 і чотиривидового гібрида 81.1546c103. Виявлене невелике відхилення від прояву показника серед самозапилення міжвидового гібриду білоруської селекції 212.31-10 і трьох популяцій за його участю. Зустрічалась як від'ємна різниця 81.436c4 x 212.31-10 (- 3,7 \%), так і додатна з комбінаціями 81.397с50 x 212.31-10 і 81.1546с103 x 212.31-10, відповідно, + 4,6 i + 1,5\%. За рідкісним винятком, комбінації за участі материнською формою шестивидового гібрида 81.436c4 та самозапилення чотиривидового гібрид 83.58c52 різниця між самозапиленням компонентів схрещування та потомства від схрещування, яке проросло на 5-9 добу, була від'ємною. Викладене також стосувалось всього пророслого насіння (лабораторна схожість), проте з іншими популяціями: 90.691/21 х Світанок київський і 81.397с50 × 212.31-10.

Значна та від'ємна різниця у прояві показника мала місце за порівняння самозапилення шестивидового гібрида 81.436с4 та двох комбінацій за його участю: - 6,7 та - 10,5\%. Аналогічне стосувалось самозапилення

Енергія проростання та лабораторна схожість насіння компонентів схрещування і гібридного ( \pm до самозапилення)

\begin{tabular}{|c|c|c|c|}
\hline Походження & $\begin{array}{c}\text { Енергія } \\
\text { про- } \\
\text { ростання } \\
\%\end{array}$ & $\begin{array}{c}\text { Проросло } \\
\text { на 5-9 } \\
\text { добу } \\
\%\end{array}$ & $\begin{array}{c}\text { Всього } \\
\text { проросло } \\
\%\end{array}$ \\
\hline $\begin{array}{c}90.691 / 21 \times \text { × С. } \\
\text { київський }\end{array}$ & $+7,1$ & $-7,0$ & $+0,2$ \\
\hline 90.694/7 x Св. київський & $-6,3$ & 0,0 & $-6,3$ \\
\hline Світанок київський & 76,3 & 12,5 & 88,8 \\
\hline $81.436 c 4 \times 212-110-12$ & $-6,7$ & $+4,6$ & $-2,1$ \\
\hline $81.436 c 4 \times 212.31-10$ & $-10,5$ & $+1,7$ & $-8,8$ \\
\hline $81.436 c 4$ & 90,0 & 4,3 & 94,3 \\
\hline $81.1546 \mathrm{c} 103 \times 212.31-10$ & $-5,3$ & $-2,1$ & $-8,6$ \\
\hline $81.1546 c 103$ x 212.47-1 & $-14,6$ & $-2,0$ & $-16,0$ \\
\hline $81.1546 c 103$ & 90,0 & 7,5 & 97,5 \\
\hline $83.58 c 52 \times 212-110-12$ & $-16,1$ & $+8,9$ & $-7,2$ \\
\hline $83.58 c 52$ & 84,2 & 9,2 & 93,3 \\
\hline $85.291 \mathrm{c} 12 \times 212-110-12$ & $-7,4$ & $-6,3$ & $-12,9$ \\
\hline $85.291 \mathrm{c} 12 \times 212.47-1$ & $-4,6$ & $-8,5$ & $-1,5$ \\
\hline $85.291 \mathrm{c} 12$ & 77,2 & 12,4 & 89,6 \\
\hline $81.397 \mathrm{c} 50 \times 212.31-10$ & $+4,6$ & $-4,4$ & $+0,2$ \\
\hline $81.436 \mathrm{c} 4 \times 212.31-10$ & $-3,7$ & $-3,2$ & $-6,9$ \\
\hline $81.1546 c 103 \times 212.31-10$ & $+1,5$ & $-5,0$ & $-3,5$ \\
\hline $212.31-10$ & 83,2 & 9,2 & 92,4 \\
\hline
\end{tabular}

чотиривидового гібрида 83.58c52 і чотиривидового гібрида 81.1546c103. Виявлене невелике відхилення від прояву показника серед самозапилення міжвидового гібриду білоруської селекції 212.31-10 і трьох популяцій за його участі. Зустрічалась як від'ємна різниця 81.436c4 x 212.31-10 (- 3,7 \%), так і додатна з комбінаціями 81.397с50 x 212.31-10 і 81.1546с103 x 212.31-10, відповідно, + 4,6 і + 1,5\%. За рідкісним винятком: комбінації за участю материнською формою шестивидового гібрида $81.436 c 4$ та самозапилення чотиривидового гібрид 83.58с52 різниця між самозапиленням компонентів схрещування та потомства за їх участю за часткою насіння, яке проросло на 5-9 добу була від'ємною. Викладене також стосувалось всього пророслого насіння (лабораторна схожість), проте з іншими популяціями: 90.691/21 х Світанок київський і 81.397с50 х 212.31-10.

Висновки. В окремих блоках комбінацій за участі однакової батьківської форми доведений значний вплив на енергію проростання гібридного насіння компонентів схрещування. Наприклад, серед серед чотирьох комбінацій із запилювачем міжвидовим гібридом білоруської селекції 212.110-12 різниця у прояві показника становила 15,2 \% 3 найменшим вираженням у комбінаціях з материнськими фрормами 83.58c52 і 85.291с12, відповідно, самозапилення чотиривидового гібрида та одноразового беккроса шестивидового гібрида.

Різниця за енергією проростання насіння у п'яти комбінаціях із запилювачем видом $S$. andigenum становила $16,1 \%$, проте у чотирьох (за винятком використання материнською фрормою одноразового беккроса шестивидового гібрида 86.96с32) вона була 9,9 \%. Близькі дані до викладених отримані у чотирьох комбінаціях за участю запилювачем міжвидового гібрида білоруської селекції 212.31-10. Виявлений специфічний вплив компонентів схрещування на проростання гібридного насіння впродовж 5-9 діб. Найвищі результати отримані серед насіння 3 походженням 86.96c32 x S. andigenum 28,3 \%. Досить високими вони були ще в трьох популяціях за участі виду. Виняток становило використання материнською формою дворазового беккроса шестивидового гібрида 89.721с81 - 9,2 \%. У 54,1 \% комбінацій лабораторна схожість насіння становила $90 \%$ і більше з максимальним проявом показника в гібридного насіння Щедрик х Подолія - 96,8 \%. В іншої популяції за участю згаданої материнської форми також отримані високі результати - 95,4%. Найвища енергія проростання насіння від самозапилення встановлена в сорту Ірбицька $(90,8 \%)$ та міжвидових гібридів 81.436с4 і 81.1546c103 по 90,0 \%. Протилежне стосувалось сорту Аніка (76,0%) та одноразового беккроса шестивидового гібрида 85.291с12 (77,2 \%). Максимальну лабораторну схожість мало насіння від самозапилення сорту Межирічка 96,0 \% та чотиривидового гібрида 81.1546с103 - 97,5\%. Виявлено, що за енергією проростання гібридне насіння поступалось виділеному від самозапилення сортів на $6,0 \%$, а міжвидових гібридів - 5,2 \%. Щодо лабораторної схожості це, відповідно, становило 3,7 та 3,1\%. Лише в окремих комбінаціях: 90.691/21 х Світанок київський, 
81.397c50 x 212.31c10 і 891.1546c103 енергія проростання насіння була вищою, ніж у насінні від самозапилення. Водночас, в популяції 83.58c52 х 212.110-12 різниця виявилась найбільшою та від'ємною - 16,1%.
Щодо лабораторної схожості насіння тільки у двох комбінаціях: 90.691/21 х Світанок київський і 81.397с50 х 212.31-10 різниця з матеріалом від самозапилення була додатною, хоча і з невеликою різницею - 0,2 \%.

\section{Бібліографічні посилання:}

1. Anasimova, I. N. (2017). Citoplazmaticheskaja muzhskaja steril'nost' i perspektivy ee ispol'zovanija v selekcionnogeneticheskih issledovanijah i semenovodstve kartofelja [Cytoplasmic male sterility and prospects for its use in breeding and genetic studies and potato seed production]. Vavilovskij zhurnal genetiki i selekcii, 21(1), 83-95 (in Russian). doi: 10.18699/VJ.226

2. Bondarchuk, A. A., Koltunov, V. A., Olijnyk, T. M., Furdyga, M. M., Vyshnevs'ka, O. V., Osypchuk, A. A., Kuprijanova, T. M. \& Zaharchuk, N. A. (2019). Kartopljarstvo: metodyka doslidnoi' spravy [Potato growing: research methodology]. TVORY, Vinnycja, 649 (in Ukrainian).

3. FAO. Food Agriculture Organization. 2010. Access mode: www.fao.org.in.

4. Hayder, A., Ahmed, M. B., Hannan, M. M., Razvy, M. A., Mandal, M. A., Salahin, M., Karim, R., \& Hossain, K. M. (2007). Analysis of genetic diversity in some potato varieties grown in Bangladesh. Middle-East Journal of Scientific Research, 2(3-4), 143-145.

5. Hniteckyi, M. O. (2021). Peculiarities of manifestation of economic traits among offspring from interspecific and intervarietal crossings of potatoes. Qualifying scientific work on the rights of the manuscript. Sumy, 198.

6. Ermishin, A. P., Voronkova, E. V., Kozlov, V. A., Roljuhovich, Ju. V., Luksha, V. I., Levyj, A. V., Jakovleva, G. A., Semanjuk, T. A., Dubinich, V. L., \& Rod'kina, I. A. (2021). Mezhvidovaja gibridizacija v selekcii kartofelja [Interspecific hybridization in potato breeding]. Belarusskaja navuka, Minsk, 396 (in Russian).

7. Gavrilenko Y. A. \& Yermishin A. H. (2017). Interspecific hybridization of potato: theoretical and applied aspects. Vavilovskij zhurnal genetiki i selekcii, 21(1), 16-29. doi: 10.18699/VJ17.220.

8. Gordijenko, V. V., \& Podgajec'kyj, A. A. (2000). Analiz skladovyh genofondu kartopli za prydatnistju dlja vyroshhuvannja z vykorystannjam botanichnogo nasinnja [Analysis of the components of the potato gene pool for suitability for cultivation using botanical seeds]. Kartopljarstvo, 30, 113-117 (in Ukrainian).

9. Kiru, S. D., \& Rogozina, U. V. (2017). Mobilizacija, sohranenie i izuchenie geneticheskih resursov kul'tiviruemogo i dikorastushhego kartofelja [Mobilization, conservation and study of the genetic resources of cultivated and wild potatoes]. Vavilovskij zhurnal genetiki i selekcii, 21(1), 7-15 (in Russian). doi: 10.18699/NJ17.219

10. Kuchumov, V. O. (1990). Shema proizvodstva kartofelja na osnove nastojanih gibridnyh semjan [Potato production scheme based on infused hybrid seeds]. Selekcija i semenovodstvo, 2, 41-43 (in Russian).

11. Meenakshi, Kumari; Manoj, Kumar; \& Shcshcank, Shekhar Solankey (2018). Breeding Potato for Quality Improvement. Submited: May 8th 2017 Reviewed: October 5-th 2017 Published; June 6th 2018. doi: 10.5772/ intechopen.71482.

12. Metodychni rekomendacii' shhodo provedennja doslidzhen' z kartopleju [Methodical recommendations for conducting research with potatoes]. (2002). IK, Nemishajeve, 183.

13. Muthoni, J., Shimelis, H., Melis, R., \& Kabira, J. (2012). Reproductive biology and early generation's selection in conventional potato breeding. Australian Journal of Crop Science, 6(3), 488-497.

14. Pershina, L. A., \& Trubacheeva, N. V. (2016). Interspecific incompatibility in wide hybridization of plants and ways to overcome. Vavilovskij zhurnal genetiki i selekcii, 20(4), 416-425. doi: 10.18699/VJ16.082.

15. Podgajec'kyj, A. A. (2002). Vyroshhuvannja kartopli z vykorystannjam botanichnogo nasinnja. Kartoplja [Growing potatoes using botanical seeds. Potato]. T.1. Bila Cerkva, 290-313 (in Ukrainian).

16. Podhaietskyi, A. A. (2012). Mezhvidovaja gibridizacija v selekcii kartofelja v Ukraine [Interspecies crosses in potato breeding in Ukraine]. Vavilov journal of genetics and breeding. 2, 16, 471-479 (in Russian).

17. Podgajec'kyj, A. A., Kravchenko, N. V., \& Gnitec'kyj, M. O. (2019). a. Projav seredn'oi' masy bul'b sered potomstva vid mizhvydovyh ta mizhsortovyh shreshhuvan' kartopli [Manifestation of the average mass of tubers among the offspring from interspecific and interspecific crossings of potatoes]. International Scientifics and practical conference Topical issues of Methods of teaching natures sciences. Poland. Lublin. December 27-28, 30-33 (in Ukrainian).

18. Podgajec'kyj, A. A., Krjuchko, L. V., \& Gnitec'kyj, M. O. (2019). b. Zhyttjezdatnist' gibrydnogo nasinnja kartopli ta vtraty materialu pid chas vyroshhuvannja sijanciv pershogo roku [Viability of hybrid potato seeds and loss of material during the cultivation of seedlings in the first year]. Visnyk Harkivs'kogo NAU. Serija «Roslynnyctvo, selekcija i nasinnyctvo, plodoovochivnyctvo i zberigannja», 2, 45-55 (in Ukrainian). doi: 10.35550/ISSN2413-7642/2019/02/05.

19. Podgaeckij, A. A., Gniteckij, M. O., Kravchenko, N. V., \& Shapoval, R. N. (2020). Produktivnost' potomstva ot mezhvidovyh i mezhsortovyh skreshhivanij kartofelja [Productivity of offspring from interspecific and intervarietal crossing of potatoes]. Sb. nauchn. tr. «Kartofelevodstvo». Minsk, 27, 24-29 (in Russian).

20. Poljuhovich, Ju. V. (2018). Geneticheskoe raznoobrazie citoplazm dikogo allotetraploidnogo vida kartofelja Solanum stoloniferum v reshenii problemy muzhskoj steril'nosti mezhvidovyh gibridov [Genetic diversity of cytoplasms of the wild allotetraploid potato species Solanum stoloniferum in solving the problem of male sterility of interspecific hybrids]. Vesci NAAN Belarusi. Ser. Biol nauk, 63(1), 33-38 (in Russian).

21. Rogozina, E. V., \& Khavkin, E. E. (2017). Interspecific potato hybrids as donors of durable resistance to pathogens. Vavylovskyj zhurnal genetyky y selekcyy, 21(1), 30-41. doi: 10/18699/VJ17.221

22. Sobran, I. V. (2019). Produktyvnist' potomstv, oderzhanyh v procesi bekkrosuvannja skladnyh mizhvydovyh gibrydiv kartopli [Productivity of offspring obtained in the process of backcrossing of complex interspecific potato hybrids. Dys. ... na zdobuttja nauk. stupenja kandydata s.-g. nauk. Sums'kyj NAU. Sumy, 215 (in Ukrainian).. 
23. Sobran, V. M., Podgajec'kyj, A. A., \& Sobran, I. V. (2021). Intensyfikacija selekcijnogo procesu kartopli z vykorystannjam umov Ukrai'ns'kyh Karpat [Intensification of potato selection process using the conditions of the Ukrainian Carpathians]. Abstracts of V International Scientific and Practical Conference: Science and Education: problems, prospects and innovetions. Kyoto, Japan 4-6 February, 895-900 (in Ukrainian).

24. Zhatova, G. O. (2010). Zagal'ne nasinnjeznavstvo [General seed science]. Navchal'nyj posibnyk. Universytets'ka knyga, Sumy, 272 (in Ukrainian).

Podhaiyetskiy A. A., Doctor (Agricultural Sciences), Professor, Sumy National Agrarian University, Sumy, Ukraine

Shapoval R. M. PhD Student, Sumy National Agrarian University, Sumy, Ukraine

Kravchenko N. V., Doctor (Agricultural Sciences), Associate Professor, Sumy National Agrarian University, Sumy, Ukraine

Germination energy and field similarity of potato seeds from crossing and self-pollination

the article presents the results of the study of germination energy of hybrid seeds with the participation of complex interspecific hybrids and their self-pollination and varieties, as well as laboratory similarity performed at Sumy National Agrarian University in 2018. In separate blocks of combinations with the participation of the same parental form, a significant effect on the germination energy of hybrid seeds of crossbreeding components has been proved. For example, among the four combinations with pollinator interspecific hybrid of Belarusian selection 212.110-12, the difference in the manifestation of the indicator was $15.2 \%$ with the least expression in combinations with maternal forms $83.58 s 52$ and 85.291 s12, respectively, self-pollination of four-species hybrid and single backcross hybrid.

The difference in seed germination energy in five combinations with the pollinator of S. andigenum was $16.1 \%$, but in four (except for the use of the mother form of a single backcross of the six-species hybrid 86.96s32) it was $9.9 \%$. Similar data to the above were obtained in four combinations with the participation of the pollinator interspecific hybrid of Belarusian selection 212.31-10. The specific influence of crossbreeding components on the germination of hybrid seeds within 5-9 days was revealed. The best results were obtained among seeds with origin $86.96 s 32 \times$ S. andigenum - $28.3 \%$. They were quite high in three more populations involving the species. The exception was the use of the mother form of double backcross sixspecies hybrid 89.721 s $81-9.2 \%$. In $54.1 \%$ of combinations, the laboratory germination of seeds was $90 \%$ or more with the maximum manifestation of the hybrid seed Shchedryk x Podoliya - 96.8\%. In another population with the participation of the mentioned maternal form also obtained high results $-95.4 \%$.

The highest energy of seed germination from self-pollination was found in the variety Irbytska (90.8\%) and interspecific hybrids $81.436 s 4$ and $81.1546 s 103-90.0 \%$ each. The opposite was true for the Anika variety (76.0 \%) and the onetime backcross of the six-species hybrid 85.291s12 (77.2\%). The maximum laboratory germination had seeds from selfpollination of Mezhyrichka variety - $96.0 \%$ and four-species hybrid $81.1546 c 103-97.5 \%$. It was found that in terms of germination energy, hybrid seeds yielded to self-pollinated varieties by $6.0 \%$, and interspecific hybrids - by $5.2 \%$, and in terms of laboratory germination, it was 3.7 and $3.1 \%$, respectively.

Only in some combinations: 90.691 / 21 x Svitanok kyivskiy, 81.397s50 x 212.31s10 and 891.1546s103 seed germination energy was higher than in seeds from self-pollination. At the same time, in the population of 83.58s52 x 212.110-12, the difference was the largest and negative $-16.1 \%$. Regarding the laboratory germination of seeds in only two combinations: 90.691 / 21 x Svitanok kyivskiy and 81.397s50 x 212.31-10 the difference with the material from self-pollination was positive, although with a small difference $-0.2 \%$.

Key words: potatoes, complex interspecific hybrids, varieties, hybrid seeds, self-pollination seeds, seed germination energy, laboratory germination. 